\title{
XBRL Adoption and Capital Market Information Efficiency
}

\author{
Lei Ruan, Northeast Normal University, China \\ Heng Liu, Northwest Normal University, China \\ Sangbing Tsai, Wuyi University, China \\ iD https://orcid.org/0000-0001-6988-5829
}

\begin{abstract}
As a common standard for global business reporting, eXtensible Business Reporting Language (XBRL) can make up for the deficiencies of traditional financial reports in terms of standardized disclosure and information use costs and provide firm-specific information to report users, reduce the level of corporate stock price synchronicity, and then improve capital market information allocation efficiency. Based on the financial data of Chinese listed companies from 2005 to 2011, this paper mainly focuses on the impact of XBRL adoption on stock price synchronicity. The research conclusions show that XBRL adoption has a significantly negative correlation with stock price synchronicity, that is, financial information disclosure in XBRL format reduces corporate stock price synchronicity level and improves Chinese capital market information efficiency. Further analysis indicates that, the alleviating effect of XBRL on stock price synchronicity can be enhanced by higher proportion of institutional investors and the state-owned nature of the actual controller. Oppositely, as analysts following continually strengthens, the alleviating effect of XBRL on stock price synchronicity decreases.
\end{abstract}

\section{KEYWORDS}

XBRL, institutional investors, analyst following, actual controller, Stock price synchronicity

\section{INTRODUCTION}

Capital market information efficiency is the timeliness, sufficiency and accuracy when securities prices react to all available information in the capital market (Fama, 1970; Grossman, 1976). In a capital market with higher information efficiency, securities prices can respond rapidly and fully to new information, and further use the signal mechanism of securities prices to realize the optimal allocation of capital resources (Borges, 2010; Gabriela ğiĠan, 2015). For the reason that securities prices can guide the flowing direction and the allocation of capital resources, the key lies in their reaction ability to the real information of enterprises, meanwhile, this reaction ability also reflects the capital market information efficiency of a country (Easley and O'hara, 2004; Kelly and Ljungqvist, 2012; Huang and Guo, 2014). Compared with mature capital markets, China, as a typical representative of the emerging capital market, is often full of "noise" in its capital market information, causing that the securities prices cannot well reflect firm-specific information, and the signal mechanism cannot be exerted smoothly, and the optimal allocation of capital resources is difficult to be achieved (Durnev et al., 2004; Li, 2010). Many studies have shown that, one important manifestation of the difference 
of information efficiency among different capital markets is stock price synchronicity (Morck et al., 2000; Chan and Hameed, 2006). Stock price synchronicity, also called the "rise and fall in lockstep" of stock prices, is the correlation between the fluctuations of stock prices of various firms and the fluctuations of average market prices (Roll, 1988; Piotroski and Roulstone, 2004; Gul et al., 2010). High stock price synchronicity indicates that only little firm-specific information is merged into stock prices. That is, the fluctuations of corporate stock prices reflect the homogeneous fluctuations of the overall prices in the capital market, rather than the heterogeneous fluctuations caused by firmspecific information (Piotroski and Roulstone, 2004; Xing and Anderson, 2011; Kim and Shi, 2012; Kim and Cheong, 2015). High stock price synchronicity weakens the ability that external investors use stock prices to identify the value of listed companies, which is not conducive to the optimal allocation of capital resources. Moreover, for China, one of the capital markets with the highest stock price synchronicity (Morck et al., 2000; Lin et al., 2015), high stock price synchronicity not only severely impairs capital market information efficiency, but also reduces the level of stock liquidity and exacerbates the risk of stock price collapses (Chan et al., 2013; Song, 2015; Jin et al., 2016). Therefore, for improving the information efficiency of Chinese capital market, it is of great theoretical and practical value to analyze the influential factors of stock price synchronicity of Chinese capital market and discuss specific measures to reduce stock price synchronicity.

Piotroski and Roulstone (2004) find that, capital market information efficiency stems from the information disclosure quality of three layers which include market information, industry information, and company information. The disclosure of market information and industry information can trigger the homogeneous fluctuations of all stock prices in the market, that is, improve stock price synchronicity. While only the disclosure layer of company information can trigger the heterogeneous fluctuations of corporate stock prices, so that reduce stock price synchronicity. Thus, an effective way to reduce stock price synchronicity is: by improving the corporate information disclosure environment and enhancing corporate information transparency, help external investors to more conveniently obtain firm-specific information, to accelerate the speed that firm-specific information is merged into stock prices, and in this way promote the heterogeneous fluctuations of corporate stock prices. As is known to all, the main way for external investors to obtain firm-specific information is the annual financial reports, however, financial reports of traditional PDF format have unavoidable deficiencies in terms of the information acquiring costs, information comparability, and sustainability (R. D. Plumlee and M. A. Plumlee, 2008; Janvrin et al., 2013), which is not conducive to the information acquisition of external investors. While in recent years, with XBRL technology emerging, this problem may be completely solved. As an important platform and tool for corporate financial information disclosure, XBRL financial reports have improved the timeliness, comparability and relevance of company accounting information, greatly reduced corporate information acquiring costs and improved the degree of convenience of external investors by collecting, collating, analyzing and storing financial data (Yoon et al., 2011; Vasarhelyi et al., 2012; Dong et al., 2016; Birt et al., 2017). However, combing through existing literature, there is little research literature about the relationship between XBRL adoption and corporate stock price synchronicity. Accordingly, can XBRL adoption affect stock price synchronicity through enhancing the disclosure of firm-specific information, and then affect capital market information efficiency? If so, what factors will play a part in the impact of XBRL adoption on stock price synchronicity? The answers to these questions are of great significance for improving Chinese capital market information efficiency.

Based on the above analysis, the main purpose of the study in this paper is: with the help of the opportunity that Chinese capital market has compulsively promoted XBRL financial reports since 2008 , to investigate the impact of XBRL adoption on capital market information efficiency, that is, whether XBRL adoption has reduced the level of stock market synchronicity of Chinese capital market. Besides, on this basis, is to discuss the impact of institutional investors, analyst following and the nature of the actual controller on the relationship between the two. The research contributions of this paper are mainly reflected in the following aspects: First, this research systematically examines the impact 
of XBRL adoption on stock price synchronicity, and explains the problem of stock price synchronicity in Chinese capital market from the perspective of corporate accounting information system. Secondly, the research in this paper also enriches relevant literature on the economic consequences of XBRL, and defines the positive impact of XBRL on the development of Chinese capital market from the perspectives of stock price synchronicity and capital market information efficiency. Finally, the research in this paper also contributes to certain policy significance for the healthy development of Chinese capital market. In recent years, China Securities Regulatory Commission and other regulatory authorities have gradually realized the disadvantages of low capital market information efficiency. And the mandatory implementation of XBRL is exactly an important measure to improve the quality of capital market information disclosure. The research conclusions of this paper show that XBRL adoption indeed reduces the stock price synchronicity of Chinese capital market and improve the level of capital market information efficiency.

The remaining parts of the paper are organized as followed: Section 2 combs through and analyzes existing literature from two perspectives: the economic consequences of XBRL and the influential factors of stock price synchronicity. Section 3 puts forward the core hypotheses of the impact of XBRL adoption on stock price synchronicity, and further expands the research hypotheses of this paper from the perspectives of institutional investors, analyst following and the nature of the actual controller. Sections 4 and 5 respectively explicitly explain the research design and empirical conclusions of this paper. Section 6 is the research conclusions of this paper and future research direction.

\section{LITERATURE REVIEW}

\section{Economic Consequences of XBRL}

As an information disclosure standard based on information technology, XBRL can store, process, and exchange financial report data in a timely, accurate, efficient, and economical manner, which contributes greatly to improving the capital market accounting information quality and the convenience of information acquisition of external investors. The research results of Hodge et al. (2004) show that XBRL users are superior to non-XBRL users in obtaining and integrating financial statement information. Baldwin et al. (2006) find that XBRL can simplify the transfer of accounting information among investors, analysts, and regulatory authorities, so that investors can have a clearer understanding of corporate accounting policies, and accordingly improve the accounting information quality. More research shows that, after the company adopts financial reports of XBRL format, it can significantly reduce the level of information asymmetry (Yoon et al., 2011), and improve the transparency of corporate financial reports (Roohani et al., 2009; Bartley et al., 2011), so that can alleviate capital market information risk, reduce the volatility level of stock returns, and improve the capital market information efficiency (Kim et al., 2012; Efendi et al., 2014; Dong et al., 2016). Some scholars have conducted research from the perspective of the impact of XBRL adoption on specific accounting information quality. For example, the study of Birt et al. (2017) shows that, the financial information of XBRL format has greater relevance, understandability and comparability than the financial information of traditional format.

Some scholars have studied the economic consequences of XBRL adoption from the perspective of corporate specific business. Alles and Piechocki (2012) believe that XBRL can be embedded in the corporate governance framework and has the potential and value in improving the corporate governance mechanism. Moreover, the research conclusions of Premuroso and Bhattacharya (2008), Roohani et al. (2009) are similar with that. The empirical evidence of Liu et al. (2014) shows that, the mandatory adoption of XBRL format financial reports can significantly improve the accuracy of analysts following and forecasting. Hao et al. (2014) find that there is a significant negative correlation between XBRL adoption and the cost of equity capital. Lai et al. (2015) find that both voluntary and mandatory XBRL financial report disclosure can reduce corporate debt cost, moreover, voluntary XBRL disclosure has a greater reduction in the debt cost. Chen et al. (2018) find that XBRL can 
enable creditors to collect and process information in a more timely and low-cost manner, so that reduce bank loan spreads. Kim et al. (2019) find that standardized official elements adopted by XBRL can reduce corporate manipulated accruals, which indicate that the implementation of XBRL can inhibit the earnings management behavior of management. The research by Zhang et al. (2019) shows that, after the adoption of XBRL by enterprises, the information processing cost is reduced, and the capital market information transparency is enhanced, which reduce investors' expectations on the risk of future stock price collapses is reduced.

\section{Influencing Factors of Stock Price Synchronicity}

In recent years, the studies of scholars about the influential factors on stock price synchronicity can be roughly divided into two aspects: First, from the perspective of financial information, it investigates the impact of information asymmetry and information transparency on stock price synchronicity. Hutton et al. (2009) find that the opacity of financial information is associated with higher $\mathrm{R}^{2}$, which indicates that enterprises disclose less firm-specific information and possess higher stock price synchronicity. The research of Song (2015) finds that, excellent accounting information disclosure policies can lead to more transparent firm information, reduce information collection costs of investors, and make corporate stock prices reflect more firm-specific information, thereby reducing stock price synchronicity. Second, from the perspective of internal and external corporate governance, it examines the impact of aspects such as corporate governance, analyst following and external system on stock price synchronicity. Gul et al. (2010) find that the level of corporate governance, including equity concentration, ratio of foreign shareholding and audit quality can all have a relatively large impact on stock price synchronicity. By increasing the content of firm-specific information in stock prices, the level of stock price synchronicity can be reduced. The research of An and Zhang (2013) finds that, institutional ownership can play a role in supervision, reduce the case that the management hide firm-specific information by management, in turn reduce corporate stock price synchronicity. Boubaker et al. (2014) find that controlling shareholders generally tend to disclose less firm-specific information in order to cover up their opportunistic behavior, which in turn leads to a higher corporate stock price synchronicity. However, this situation is impossible if the controlling shareholder possesses larger cash flow rights. Piotroski and Roulstone (2004), Chan and Hameed (2006) find that, the more the number of individuals in analysts following, the higher level corporate stock price synchronicity will show. The research of Liu (2011), Xu et al. (2013) and Huang et al. (2016) find that, analysts following can provide more information about firm-specific information, accordingly effectively reducing corporate stock price synchronicity level. Kim et al. (2016) find that, corporate information transparency is enhanced through the information collection and exposure by information intermediaries such as news agencies and analyst following, so that stock price synchronicity is reduced. Hasan et al. (2014) use data at the provincial level in China to prove that a well-established legal and political system can provide more firm-specific information, and reduce stock price synchronicity.

\section{HYPOTHESIS DEVELOPMENT}

\section{XBRL Adoption and Stock Price Synchronicity}

For the formation of capital market stock price synchronicity, it can be significantly attributed to information asymmetry and opacity (Hutton et al., 2009). Due to the widespread existence of principal-agent problem, it is difficult for external investors to obtain firm-specific information in a timely and effective manner, causing that little company information is merged into stock prices; accordingly the rise of stock price synchronicity level is promoted (Jin and Myers, 2006). Especially, in China, a typical country of emerging market, strong government supervision, weak property rights protection and imperfect corporate governance system have even further promoted the rise of stock 
price synchronicity level (Morck et al., 2000; Lin et al., 2015). Existing studies have shown that, for reducing stock price synchronicity, the important methods are to increase proactive information disclosure, strengthen corporate governance, reduce the degree of corporate information asymmetry, and enable more firm-specific information to be merged into stock prices (Song, 2015). For external investors, an important approach to obtain firm-specific information is traditional PDF financial reports. Financial reports in this format require information users to have certain professional qualities to independently search for the required information, moreover, there is lower information timeliness and comparability in this format, as well as higher information acquiring costs for investor, which directly cause that little firm-specific information is merged into stock prices. While XBRL is an open, authorization-exempt, cross-platform business and financial data exchange language, which enables financial and business reporting data to be stored, processed, and communicated in a timely, accurate, and efficient manner (Richardset al., 2006). Many studies have shown that XBRL adoption can effectively reduce the degree of corporate information asymmetry, improve information transparency, and help external investors to obtain firm-specific information with more convenience and lower costs (Baldwin et al., 2006; Roohani et al., 2009; Bartley et al., 2011; Yoon et al., 2011;). All of these can help more firm-specific information to be merged into stock prices, thereby reduce the level of stock price synchronicity.

At current stage, both Shanghai Stock Exchange and Shenzhen Stock Exchange require listed companies to generate XBRL financial reports through software or online reporting, besides disclosing traditional PDF financial reports. From the perspective of signal transmission theory, it is equivalent to a listed company sending out more signals about company characteristics, which is convenient for investors to obtain and use. At the same time, the issuance of this signal has further reduced the degree of information asymmetry between companies and investors (Yoon et al., 2011), which is conducive to investors' decision-making. Thus, it can also to a certain extent speed up the process in which firm-specific information is merged into stock prices, and reduce stock price synchronicity.

Based on the above analysis, we propose the research hypothesis 1 .

H1: XBRL adoption can effectively reduce corporate stock price synchronicity and improve capital market information efficiency.

\section{Institutional Investors and Stock Price Synchronicity}

Existing studies have shown that, when the proportion of institutional investors is high in a company, it can effectively play its role in supervision, and can reduce the possibility of internal company managers hiding firm-specific information, and can accordingly promote the integration of firmspecific information into stock prices and reduce stock price synchronicity (Piotroski and Roulstone, 2004; An and Zhang, 2013). In general, institutional investors, as important investment subjects in capital markets, should have stronger ability to obtain and interpret information than retail investors. Institutional investors usually tend to use the firm-specific information they own to trade, which increases the content of firm-specific information in stock prices, as well as reduces the probability that stock prices will be affected by market noise. Therefore, when the company adopts financial reports in XBRL format, the comparability and timeliness of information will be greatly improved, and more firm-specific information will be captured by professional institutional investors, and further reflected in corporate stock prices, leading to a lower level of stock price synchronicity.

Based on the above analysis, we propose the research hypothesis 2.

H2: With the increase in the proportion of institutional investors, XBRL adoption has a stronger alleviating effect on stock price synchronicity. 


\section{Analyst Following and Stock Price Synchronicity}

The correlation between analysts following and stock price synchronicity has been recognized by most scholars. However, there is no unified conclusion as to whether analysts following influences stock price synchronicity in a positive or negative direction. Piotroski and Roulstone (2004), Chan and Hameed (2006) find that, the more the number of individuals in analysts following, the higher level corporate stock price synchronicity will show. Liu (2011), Xu et al. (2013), Huang et al. (2016), Kim et al. (2016) find that analysts following can provide more firm-specific information, in turn can effectively reduce corporate stock price synchronicity level. The key for the difference between the two is whether the analysts following provides more information of market and industry levels, or provides more firm-specific information (Huang and Guo, 2014). With the mandatory adoption of XBRL format financial reports by listed companies, if securities analysts use XBRL to provide more firm-specific information, there is no doubt that it will further reduce stock price synchronicity. Conversely, if securities analysts provide more information of market and industry levels, the role of XBRL in reducing stock price synchronicity will inevitably be affected to some extent.

Based on the above analysis, we propose the competitive hypotheses $3 \mathrm{a}$ and $3 \mathrm{~b}$.

H3a: With the enhancement of analysts following, the alleviating effect of XBRL adoption on stock price synchronicity will increase.

$\mathrm{H} 3 \mathrm{~b}$ : With the enhancement of analysts following, the alleviating effect of XBRL adoption on stock price synchronicity will weaken.

\section{The Nature of the Actual Controller and Stock Price Synchronicity}

The influence of the nature of the actual controller on the relationship between XBRL adoption and stock price synchronicity is mainly reflected in the following two aspects: First, compared with private enterprises, state-owned enterprise executives are usually appointed by the administration, so that they always tend to not disclose or disclose little firm-specific information out of their private interests in the right of control. Besides, state-owned enterprises usually have inherent advantages in policy and capital, and often face fewer financing constraints, which directly leads to weaker signal transmission function undertaken by financial reports during their financing processes, as well as the lack of motivation and incentives to improve accounting information disclosure quality. However, with the compulsory implementation of China's XBRL financial reports, state-owned enterprises and non-state-owned enterprises implement unified financial information disclosure standards, in this way, compared with the consistent high-quality information disclosure level of non-state-owned enterprises, state-owned enterprises will release more firm-specific information. After the firmspecific information is captured by investors, it will further reduce the stock price synchronicity of state-owned enterprises. Second, XBRL is a mandatory measure promoted by Chinese government, so state-owned enterprises often have a greater incentive to promote and complete it than private enterprises. Large-scale state-owned enterprises such as China Petroleum Group and Sinopec-China Petroleum responded immediately, and actively explored the application of XBRL to internal enterprise management. Therefore, we expect that the impact of XBRL adoption on stock price synchronicity in state-owned enterprises will be significantly greater than that in non-state-owned enterprises.

Based on the above analysis, we propose the hypothesis 4 .

H4: Compared with non-state-owned actual controllers, actual controllers with the state-owned nature can enhance the alleviating effect of XBRL adoption on stock price synchronicity. 
Table 1. Sample selection

\begin{tabular}{|l|c|c|}
\hline & Companies & Samples \\
\hline Initial samples(2005-2011) & 1446 & 9435 \\
\hline Subtract: listed companies in 2008 & $(1)$ & $(1332)$ \\
\hline $\begin{array}{l}\text { Subtract: samples with less than 30 observations of individual stock weekly return } \\
\text { data }\end{array}$ & $(49)$ & $(389)$ \\
\hline Subtract: listed companies from financial and insurance industries & $(34)$ & $(160)$ \\
\hline Subtract: ST and *ST listed companies & $(27)$ & $(826)$ \\
\hline Subtract: missing data listed companies & $(460)$ & $(1478)$ \\
\hline Final samples(2005-2007, 2009-2011) & 875 & 5250 \\
\hline
\end{tabular}

\section{RESEARCH DESIGN}

\section{Data and Sample Selection}

In the early stage of the study, this paper explicitly studied the time course of the implementation of XBRL financial reports by Shanghai Stock Exchange and Shenzhen Stock Exchange. It has been found that since the 2008 annual reports, all listed companies must disclose both traditional financial reports (PDF format) and XBRL format financial reports. So this paper intends to use 2008 as the first year of China's XBRL implementation, and selects data from the two three-year periods respectively before and after 2008, that is, research samples from 2005 to 2011 to explore the impact of XBRL implementation on Chinese capital market information efficiency. At the same time, referring to the processing method of Chen et al. (2015), in view of the strong impact of the global financial crisis in 2008 on the capital market, the 2008 data is deleted, and the year 2009 is used uniformly as the first year after the implementation of XBRL. During the research process, except that the stock price synchronicity index is calculated manually, all other required data come from the CSMAR database.

In this paper, the data selection process is as followed: referring to the processing method of Morck et al. (2000) on stock price synchronicity index, this paper excludes samples with less than 30 observations of individual stock weekly return data; excludes listed companies from financial and insurance industries; excludes ST and *ST companies; in order to ensure the comparability and robustness of the research conclusions, this paper also requires that there are no missing data for a total of 6 years from $t-3$ to $t-1$ and from $t+1$ to $t+3$. Therefore, in this way, some missing data samples are deleted. Finally, a research sample of 5250 observations, 875 listed companies is formed. The sample selection process is shown in Table 1.

\section{VARIABLES}

\section{Dependent Variable}

In this paper, stock price synchronicity is selected as a substitute variable of capital market information efficiency. According to the processing methods of Durnev et al. (2003), Jin and Myers (2006), K. Chan and YC Chan (2014), for companies with at least 30 weekly returns in that year, after the regression taken according to the following model 1, the adjusted fitting coefficient $\mathrm{R}^{2}$ is obtained. In model $1, R_{i, t}$ refers to the return rate of stock $\mathrm{i}$ in week $\mathrm{t}$ considering the reinvestment of cash dividends, and $R_{m, t}$ refers to the weighted average rate of return of all A shares in week that is weighted by circulation market value; $R_{l, t}$ is the average rate of return obtained by the weighted $R_{i, t}$ 
whose weight is enterprise circulating market value, according to the industry classification standards of China Securities Regulatory Commission in 2012.

$$
R_{i, t}=\beta_{0}+\beta_{1} R_{m, t}+\beta_{2} R_{l, t}+\varepsilon_{i, t}
$$

After using model 1 to make regression on individual stocks one by one, the fitting goodness $\mathrm{R}^{2}$ of each company over the years can be obtained. Since the value of $\mathrm{R}^{2}$ range from 0 to 1 , it does not meet the principle of normal distribution. Therefore, it is necessary to further conduct logarithmic treatment on $\mathrm{R}^{2}$, as seen in Model 2, finally make the stock price synchronicity index follow the normal distribution as much as possible.

$$
S Y N C H_{i, t}=\ln \left(\frac{R_{i}^{2}}{1-R_{i}^{2}}\right)
$$

Among them, $S Y N C H_{i, t}$ is used to measure stock price synchronicity of stock $\mathrm{i}$ in year $\mathrm{t}$. $S Y N C H_{i, t}$ is higher, indicating that more individual stock fluctuations will be explained by market fluctuations and industry fluctuations, thereby the " rise and fall in lockstep" phenomenon in the stock market will be severer, firm-specific information contained in stock prices will be less, and capital market information efficiency will be lower.

\section{Independent Variable}

The core independent variable studied in this paper is XBRL. XBRL can achieve information sharing and interoperability in the securities industry and between industries, playing a significant role in promoting the development of information disclosure and securities information services of Chinese listed companies. In December 2003, Shanghai Stock Exchange selected 50 local listed companies in Shanghai as application pilots. In February 2005, Shenzhen Stock Exchange also began piloting the application of XBRL technology. Based on extensive pilots, both Shanghai Stock Exchange and Shenzhen Stock Exchange have mandated that starting from annual reports in 2008, all listed companies need to disclose financial reports in traditional format (PDF format) and financial reports in XBRL format. At the same time, referring to the processing method of Chen et al. (2015), which considers the strong impact of the global financial crisis in 2008 on the capital market, the 2008 data is deleted, and year 2009 is uniformly used as the first year after the implementation of XBRL. Therefore, we set 0 for the listed companies before the implementation of XBRL, and then set 1 for those after the implementation of XBRL.

\section{Moderating Variable}

There are mainly three moderating variables involved in the research process of this paper. The first is the proportion of institutional investors. It is measured by the ratio of the number of institutional investors to the number of company's total share capital at the end of the year. The institutional investors involved in this study include: funds, securities firms, QFII, insurance companies, and social security funds, etc. The second is analyst following. For reference of the common processing method of existing research (Kim and Shi, 2012; Harjoto and Jo, 2015; Li et al., 2019), analyst following is equivalent to the value of the natural logarithm of the number of securities analyst number conducting analysts following analysis plus 1 . The third is the nature of the actual controller. It is determined by the nature of listed company shares possessed by the actual controller disclosed in listed company 
Table 2. Variable definitions

\begin{tabular}{|l|l|}
\hline \multicolumn{1}{|c|}{ Variable } & \multicolumn{1}{c|}{ Definition } \\
\hline SYNCH & $\begin{array}{l}\text { The stock price synchronicity variable is calculated based on the } \mathrm{R}^{2} \text { of the company's stock returns } \\
\text { and market and industry returns. }\end{array}$ \\
\hline XBRL & Dummy variable, the listed company adopts XBRL as 1 and before as 0 \\
\hline Inshold & The ratio of shares held by all institutional investors to total shares \\
\hline Analyst & The natural logarithm of one plus the number of analysts following the firm \\
\hline Controller & $\begin{array}{l}\text { State-owned dummy variable, when the company's ultimate control for state-owned single or state- } \\
\text { owned legal person, the value is } 1, \text { otherwise } 0\end{array}$ \\
\hline Size & The natural log of total assets at the end of the year \\
\hline Lev & Total liabilities/total assets \\
\hline Central & The shareholding of the largest shareholder \\
\hline Volume & Natural logarithm of total annual stock transactions \\
\hline Big4 & If the company's audit unit is the "Big Four" accounting firm, the value is 1, otherwise 0 \\
\hline Roa & Net profit/total assets \\
\hline Mb & Market value/book value \\
\hline Ind & Industry dummy variables \\
\hline Year & Annual dummy variable \\
\hline
\end{tabular}

annual reports. If the nature of the shareholding is state-owned, the value is 1 ; if it is non-state-owned, then the value is 0 .

Control Variable In view of the studies of Gul et al. (2010), Chung et al. (2011), Kim and Shi (2012), Xu et al. (2013), this paper also selects other control variables that may affect stock price synchronicity. Specifically, they include: enterprise size (Size), debt level (Lev), equity concentration (Central), stock annual volume (Volume), audit quality (Big4), growth level (ROA) and market-tobook ratio $(\mathrm{Mb})$. Finally, the dummy variables, year and industry are added to control the interference of time and industry factors. The specific variable definitions are shown in Table 2.

\section{Model Specification}

In order to verify the hypothesis $\mathrm{H} 1$, the stock price synchronicity index (SYNCH) calculated by the above models (1) and (2) is used as the dependent variable, and the dummy variable manifesting whether XBRL is implemented is used as the independent variable, and the measurement model (3) is constructed as followed:

$$
\text { SYNCH }=\beta_{0}+\beta_{1} X B R L+\beta_{2} \text { Inshold }+\beta_{3} \text { Analyst }+\beta_{4} \text { Controller }+\beta_{5} \text { Others }+ \text { Ind }+ \text { Year }+\varepsilon
$$

In order to verify the hypothesis $\mathrm{H} 2$, the crossover term XBRL * Inshold of institutional investors and XBRL is added to the above model (3). Then the model (4) is constructed as followed:

$$
S Y N C H=\beta_{0}+\beta_{1} X B R L+\beta_{2} \text { Inshold }+\beta_{3} X B R L^{*} \text { Inshold }+\beta_{4} \text { Analyst }+\beta_{5} \text { Controller }+\beta_{6} \text { Others }+ \text { Ind }+ \text { Year }+\varepsilon
$$


Among them, XBRL* Inshold, the crossover term of XBRL and Inshold, represents the interaction effect of institutional investors and XBRL, which can capture the influential difference of XBRL on stock price synchronicity at different levels of institutional investors.

In order to verify the hypotheses $\mathrm{H} 3 \mathrm{a}$ and $\mathrm{H} 3 \mathrm{~b}$, the crossover term XBRL * Analyst of securities analyst following and XBRL is added to the above model (3). Then the model (5) is constructed as followed:

$S Y N C H=\beta_{0}+\beta_{1} X B R L+\beta_{2}$ Inshold $+\beta_{3}$ Analyst $+\beta_{4} X B R L^{*}$ Analyst $+\beta_{5}$ Controller $+\beta_{6}$ Others + Ind + Year $+\varepsilon$

Among them, the crossover item of XBRL and Analyst-XBRL* Analyst indicates the interaction effect between analyst following and XBRL, and can capture the difference in the impact of XBRL on the synchronicity of stock prices at different levels of analyst following.

In order to verify the hypothesis $\mathrm{H} 4$, the crossover term XBRL * Controller of the nature of the actual controller and XBRL is added to the above model (3), and the model (6) is constructed as followed:

SYNCH $=\beta_{0}+\beta_{1} X B R L+\beta_{2}$ Inshold $+\beta_{3}$ Analyst $+\beta_{4}$ Controller $+\beta_{5}$ XBRL $L^{*}$ Controller $+\beta_{6}$ Others + Ind + Year $+\varepsilon$

Among them, the crossover item XBRL * Controller of XBRL and Controller represents the interaction effect between the nature of the actual controller and XBRL, which can capture the difference in the influence of XBRL on stock price synchronicity under different nature of the actual controller.

\section{RESULTS}

\section{Descriptive Statistics}

Table 3 reports the descriptive statistical results of main variables. Among them, the mean value of stock price synchronicity index is -0.5498 , the median of it is -0.4584 , and the standard deviation of it is 0.7728 , manifesting that stock price synchronicity largely varies among different companies. The average ratio of listed company institutional investors reaches $5.75 \%$, and the mean of analyst following is 1.3424 . In the overall sample, the number of enterprises with the state-owned nature of actual controllers accounts for $48 \%$, which indicates that the state-owned enterprise is still an important pillar of our national economy. The mean value of corporate assets is 21.8894 , and the average debt ratio is $50.54 \%$. The average shareholding of the largest shareholder is $36.98 \%$, which indicates that the phenomenon of "only one big share" among Chinese listed companies is still relatively serious. The average annual transaction volume of the entire samples is 20.9401; the proportion of the international "Big four" audit companies is $8 \%$; the return on total assets is $4.03 \%$, and the average value of the market-to-book ratio is 1.8256 .

\section{Univariate Analysis}

Table 4 lists the results of the mean $\mathrm{T}$ test and median Wilcoxon test for each indicator before and after the implementation of XBRL. As can be seen from the table, the mean and median of stock price synchronicity have both decreased significantly after XBRL adoption, which indicate that with the mandatory implementation of XBRL, the stock price synchronicity of sample companies has significantly decreased. This also preliminarily verified the research hypothesis H1 in this paper. Most of the other indicators also show that with the implementation of XBRL, there is significant rise 
Table 3. Descriptive statistics

\begin{tabular}{|c|c|c|c|c|c|}
\hline Variable & Mean & Std.dev & Min & Median & Max \\
\hline SYNCH & -0.5498 & 0.7728 & -9.6408 & -0.4584 & 1.5615 \\
\hline XBRL & 0.50 & 0.500 & 0 & 0.50 & 1 \\
\hline Inshold & 0.0575 & 0.0915 & 0 & 0.0117 & 0.7505 \\
\hline Analyst & 1.3424 & 1.1323 & 0 & 1.0986 & 4.1897 \\
\hline Controller & 0.48 & 0.500 & 0 & 0 & 1 \\
\hline Size & 21.8894 & 1.1553 & 18.6160 & 21.7515 & 27.7533 \\
\hline Lev & 0.5054 & 0.1776 & 0.0071 & 0.5188 & 1.2517 \\
\hline Central & 0.3698 & 0.1559 & 0.0362 & 0.3549 & 0.8523 \\
\hline Volume & 20.9401 & 1.0731 & 14.3948 & 21.0561 & 25.0955 \\
\hline Big4 & 0.08 & 0.267 & 0 & 0 & 1 \\
\hline Roa & 0.0403 & 0.0511 & -0.4360 & 0.0340 & 0.3809 \\
\hline Mb & 1.8256 & 1.1157 & 0.7590 & 1.4695 & 15.1135 \\
\hline
\end{tabular}

to various degrees in following aspects of sample companies: institutional ownership ratio, analyst following, total assets, debt level, annual transaction volume and market-to-book ratio; while there is significant decrease in equity concentration.

\section{Multivariate Analysis}

Table 5 reports how XBRL adoption affects the regression results of stock price synchronicity. As can be seen from the data, the coefficient of XBRL is -0.2128 , and it is significant at the level of $1 \%$, which shows that the implementation of XBRL has indeed reduced corporate stock price synchronicity. The regression results also shows that with the mandatory implementation of XBRL financial reports, the degree of company information asymmetry has been reduced, and the information transparency has been improved. More and more firm-specific information has been captured by investors and been merged into stock prices, reducing corporate stock price synchronicity. At the same time, the implementation of XBRL has also strengthened the signal transmission mechanism of corporate

Table 4. Comparison of the difference of variables before and after XBRL adoption

\begin{tabular}{|c|c|c|c|c|c|c|c|c|}
\hline & \multicolumn{2}{|c|}{ XBRL=0 } & \multicolumn{2}{c|}{ XBRL=1 } & \multicolumn{2}{c|}{ T test } & \multicolumn{2}{c|}{ Wilcoxon test } \\
\hline & Mean & Median & Mean & Median & Diff. & T value & Diff. & Z value \\
\hline SYNCH & -0.6312 & -0.5235 & -0.4684 & -0.3834 & 0.1628 & $7.675 * * *$ & 0.1401 & $-8.311^{* * *}$ \\
\hline Inshold & 0.0509 & 0.0059 & 0.0642 & 0.0186 & 0.0133 & $5.279 * * *$ & 0.0127 & $-7.168 * * *$ \\
\hline Analyst & 0.9678 & 0.6931 & 1.7169 & 1.7918 & 0.7491 & $25.397 * * *$ & 1.0987 & $-23.368 * * *$ \\
\hline Size & 21.5951 & 21.5072 & 22.1837 & 22.0227 & 0.5886 & $19.084 * * *$ & 0.5155 & $-18.761 * * *$ \\
\hline Lev & 0.4941 & 0.5093 & 0.5167 & 0.5318 & 0.0226 & $4.622^{* * *}$ & 0.0225 & $-4.820^{* * *}$ \\
\hline Central & 0.3829 & 0.3680 & 0.3567 & 0.3383 & -0.0262 & $-6.116^{* * *}$ & -0.0297 & $6.237 * * *$ \\
\hline Volume & 20.4698 & 20.4514 & 21.4103 & 21.4127 & 0.9405 & $35.318^{* * *}$ & 0.9613 & $-31.964 * * *$ \\
\hline Roa & 0.0392 & 0.0337 & 0.0414 & 0.0342 & 0.0022 & 1.572 & 0.0005 & -0.451 \\
\hline Mb & 1.5708 & 1.2571 & 2.0804 & 1.7011 & 0.5096 & $16.993 * * *$ & 0.444 & $-22.839 * * *$ \\
\hline
\end{tabular}


Table 5. Regression results of XBRL adoption and Stock Price Synchronicity

\begin{tabular}{|c|c|c|c|}
\hline Variable & Coff. & T value & $P$ value \\
\hline Constant & $-3.1929 * * *$ & -1.25 & 0.000 \\
\hline XBRL & $-0.2128 * * *$ & -4.72 & 0.000 \\
\hline Inshold & $-0.8490 * * *$ & -6.38 & 0.000 \\
\hline Analyst & $-0.0477 * * *$ & -3.51 & 0.000 \\
\hline Controller & $-0.0649 * * *$ & -2.89 & 0.000 \\
\hline Size & $0.0807 * * *$ & 4.73 & 0.000 \\
\hline Lev & $-0.5435^{* * *}$ & -7.94 & 0.000 \\
\hline Central & -0.0739 & -1.02 & 0.308 \\
\hline Volume & $0.0816^{* * *}$ & 5.14 & 0.000 \\
\hline Big4 & $-0.2125 * * *$ & -5.29 & 0.000 \\
\hline Roa & -0.0373 & -0.16 & 0.876 \\
\hline $\mathrm{Mb}$ & $-0.1893 * * *$ & -16.03 & 0.000 \\
\hline Obs & & 5250 & \\
\hline Ind & & YES & \\
\hline Year & & YES & \\
\hline Adj. $R^{2}$ & & 0.1864 & \\
\hline
\end{tabular}

financial information, broadened the channels and methods for investors to obtain firm-specific information, and has further led to a reduction in stock price synchronicity. In summary, XBRL adoption helps company information be merged into stock prices and reduce stock price synchronicity, thus has verified the research hypothesis $\mathrm{H} 1$ in this paper.

The regression results of other indicators show that the proportion of institutional investors is negatively correlated with stock price synchronicity. This means that institutional investors rely more on firm-level information when making investment decisions, which will help the degree to which firm-specific information is integrated into the stock price and further reduce the level of company stock price synchronicity.; Analyst following make more company information merged into stock prices, reducing corporate stock price synchronicity; Compared with non-state-owned companies, the share price content of state-owned enterprises contains more company information; Enterprise size is positively related to stock price synchronicity; Debt level has a negative correlation with stock price synchronicity; Annual stock trading volume is negatively correlated with stock price synchronicity; Big four audit companies have lower stock price synchronicity; Finally, the market-to-book ratio index has a negative correlation with stock price synchronicity.

Table 6 further examines how the impact of XBRL adoption on corporate stock price synchronicity is affected by institutional ownership, analyst following, and the nature of the actual controller. The multiple regression results in column (1) of Table 6 show that the estimated coefficient of the crossover term of XBRL and institutional investors is -0.5667 , which is significant at the level of $1 \%$. This shows that with the increasing proportion of institutional investors, the alleviating effect of XBRL on stock price synchronicity becomes more and more obvious, which also validates the research hypothesis $\mathrm{H} 2$ in this paper. This result shows once again that for stock trading of institutional investors, company information is used more. Therefore, with the implementation of XBRL, more firm-specific information will be released, and the trading behavior of institutional investors will 
cause more firm-specific information to be merged into the stock price, resulting in lower stock price synchronicity.

The multiple regression results of the analyst following in column (2) show that the crossover term coefficient of XBRL and analyst following is 0.0106, but it is not significant. This shows that with the gradual increase in analyst following, the alleviating effect of XBRL on stock price synchronicity has decreased. The research hypothesis $\mathrm{H} 3 \mathrm{~b}$ in this paper is partially verified. This may be because analyst following reflects market and industry information more, which ultimately leads to a reduction in the alleviating effect of XBRL on stock price synchronicity. Column (3) is the multiple regression results of the actual controller. The crossover term coefficient of XBRL and the actual controller is -0.0583 , but it is not significant. This shows that compared with non-stateowned companies, XBRL in state-owned companies has a stronger alleviating effect on stock price synchronicity, which also partially validates the research hypothesis $\mathrm{H} 4$ in this paper. This may be due to the fact that with the implementation of XBRL, state-owned enterprises invested more resources and attention, and released more firm-specific information on company characteristics, so that more firm-specific information is merged into their stock prices, accordingly the degree of reduction in stock price synchronicity increases.

In order to avoid the influence of the omission of variables on the research conclusions in this paper, column (4) of Table 6 involves all three crossover terms in the regression model. The research conclusions show that the coefficient of XBRL*Inshold is -0.8640 , and it is significant at the level of $1 \%$, which again verifies the hypothesis $\mathrm{H} 2$. The coefficient of XBRL*Analyst is 0.0502 , and it is significant at the level of $5 \%$, which also fully validates the research hypothesis $\mathrm{H} 3 \mathrm{~b}$ in this paper. The coefficient of XBRL*Controller is -0.0747 , and it is significant at the level of $10 \%$, which entirely verifies the research hypothesis $\mathrm{H} 4$ in this paper.

\section{CONCLUSIONS}

XBRL, as the major technological change in corporate financial information field, has been proved that it is able to reduce the degree of information asymmetry and enhance the information transparency of enterprises. Government regulatory agencies of various countries are also actively promoting the application of XBRL technology in the management of listed companies. The research in this paper is based on the perspective of capital market information efficiency, mainly focuses on the impact of XBRL adoption on stock price synchronicity. With the institutional background of the mandatory implementation of XBRL in Chinese listed companies, this paper uses the relevant data of Chinese listed companies from 2005 to 2011 to empirically test the impact of XBRL adoption on stock price synchronicity. The research conclusions show that there is a significantly negative correlation between XBRL adoption and stock price synchronicity, that is, XBRL format information disclosure reduces corporate stock price synchronicity level, which is consistent with the explanation that XBRL offers more firm-specific information. Further analysis shows that higher proportion of institutional investors and the state-owned nature of the actual controller can enhance the alleviating effect of XBRL on stock price synchronicity. Conversely, as analysts following continually strengthens, the alleviating effect of XBRL on stock price synchronicity decreases. In conclusion, the research in this paper shows that, XBRL adoption can significantly enhance the speed at which firm-specific information is merged into stock prices, which ultimately leads to a reduction in stock price synchronicity. And this negative correlation is also affected by the proportion of institutional investors, analysts following and the nature of the actual controller.

Since 2008, all listed companies in the Chinese capital market must disclose both traditional financial reports (PDF) and XBRL financial reports. Based on the observation of the literature and facts, we found that the application of XBRL financial reports has indeed played a significant role in enhancing the information transparency, improving the information disclosure system, reducing the stock price synchronicity and improving the capital market information efficiency. However, 
Table 6. Multiple regression results with moderating variables

\begin{tabular}{|c|c|c|c|c|}
\hline Variable & (1) & (2) & (3) & (4) \\
\hline Constant & $\begin{array}{c}-3.3495 \\
(-10.46) * * *\end{array}$ & $\begin{array}{c}-3.3736 \\
(-10.28) * * *\end{array}$ & $\begin{array}{c}-3.3088 \\
(-10.30) * * *\end{array}$ & $\begin{array}{c}-3.4600 \\
(-10.53) * * *\end{array}$ \\
\hline XBRL & $\begin{array}{c}-0.2159 \\
(-4.79) * * *\end{array}$ & $\begin{array}{c}-0.2132 \\
(-4.72) * * *\end{array}$ & $\begin{array}{c}-0.2101 \\
(-4.65) * * *\end{array}$ & $\begin{array}{c}-0.2160 \\
(-4.78) * * *\end{array}$ \\
\hline Inshold & $\begin{array}{c}-0.8306 \\
(-6.24)^{* * *}\end{array}$ & $\begin{array}{c}-0.8443 \\
(-6.33) * * *\end{array}$ & $\begin{array}{c}-0.8480 \\
(-6.37) * * *\end{array}$ & $\begin{array}{c}-0.7973 \\
(-5.96) * * *\end{array}$ \\
\hline XBRL*Inshold & $\begin{array}{c}-0.5667 \\
(-2.65) * * *\end{array}$ & & & $\begin{array}{c}-0.8640 \\
(-3.51) * * *\end{array}$ \\
\hline Analyst & $\begin{array}{c}-0.0467 \\
(-3.44) * * *\end{array}$ & $\begin{array}{c}-0.0489 \\
(-3.56) * * *\end{array}$ & $\begin{array}{c}-0.0465 \\
(-3.42) * * *\end{array}$ & $\begin{array}{c}-0.0506 \\
(-3.67) * * *\end{array}$ \\
\hline XBRL*Analyst & & $\begin{array}{l}0.0106 \\
(0.57)\end{array}$ & & $\begin{array}{c}0.0502 \\
(2.33) * *\end{array}$ \\
\hline Controller & $\begin{array}{c}-0.0621 \\
(-2.76)^{* * *}\end{array}$ & $\begin{array}{c}-0.0652 \\
(-2.90) * * *\end{array}$ & $\begin{array}{c}-0.0665 \\
(-2.96) * * *\end{array}$ & $\begin{array}{c}-0.0644 \\
(-2.86) * * *\end{array}$ \\
\hline XBRL*Controller & & & $\begin{array}{c}-0.0583 \\
(-1.36)\end{array}$ & $\begin{array}{l}-0.0747 \\
(-1.72) *\end{array}$ \\
\hline Size & $\begin{array}{c}0.0820 \\
(4.82)^{* * *}\end{array}$ & $\begin{array}{c}0.0798 \\
(4.66) * * *\end{array}$ & $\begin{array}{c}0.0810 \\
(4.75) * * *\end{array}$ & $\begin{array}{c}0.0791 \\
(4.63) * * *\end{array}$ \\
\hline Lev & $\begin{array}{c}-0.5518 \\
(-8.06)^{* * *}\end{array}$ & $\begin{array}{c}-0.5425 \\
(-7.92) * * *\end{array}$ & $\begin{array}{c}-0.5446 \\
(-7.95) * * *\end{array}$ & $\begin{array}{c}-0.5531 \\
(-8.08) * * *\end{array}$ \\
\hline Central & $\begin{array}{l}-0.0810 \\
(-1.12)\end{array}$ & $\begin{array}{c}-0.0713 \\
(-0.98)\end{array}$ & $\begin{array}{c}-0.0809 \\
(-1.11)\end{array}$ & $\begin{array}{c}-0.0815 \\
(-1.12)\end{array}$ \\
\hline Volume & $\begin{array}{c}0.0805 \\
(5.07) * * *\end{array}$ & $\begin{array}{c}0.0828 \\
(5.17) * * *\end{array}$ & $\begin{array}{c}0.0802 \\
(5.04) * * *\end{array}$ & $\begin{array}{c}0.0837 \\
(5.22) * * *\end{array}$ \\
\hline Big4 & $\begin{array}{c}-0.2152 \\
(-5.36) * * *\end{array}$ & $\begin{array}{c}-0.2110 \\
(-5.24) * * *\end{array}$ & $\begin{array}{c}-0.2131 \\
(-5.30) * * *\end{array}$ & $\begin{array}{c}-0.2105 \\
(-5.24) * * *\end{array}$ \\
\hline Roa & $\begin{array}{c}-0.0614 \\
(-0.26)\end{array}$ & $\begin{array}{c}-0.0303 \\
(-0.13)\end{array}$ & $\begin{array}{c}-0.0457 \\
(-0.19)\end{array}$ & $\begin{array}{c}-0.0516 \\
(-0.22)\end{array}$ \\
\hline $\mathrm{Mb}$ & $\begin{array}{c}-0.1884 \\
(-15.95)^{* * *}\end{array}$ & $\begin{array}{c}-0.1892 \\
(-16.01) * * *\end{array}$ & $\begin{array}{c}-0.1910 \\
(-16.08) * * *\end{array}$ & $\begin{array}{c}-0.1895 \\
(-15.96) * * *\end{array}$ \\
\hline Obs & 5250 & 5250 & 5250 & 5250 \\
\hline Ind & YES & YES & YES & YES \\
\hline Year & YES & YES & YES & YES \\
\hline Adj.R2 & 0.1874 & 0.1863 & 0.1865 & 0.1882 \\
\hline
\end{tabular}

problems also exist, for instance, in terms of the disclosure costs, application promotion and popularization. Therefore, we believe that the advancement of XBRL financial reports in the Chinese capital market can be started from the following aspects: First, communication and coordination should be strengthened among various regulatory agencies of the government, and a unified XBRL technical standard and comprehensive service platform should be formulated as soon as possible to reduce the technical predicament and cost pressures of enterprises in terms of XBRL disclosure. Secondly, although currently XBRL financial reports have entered the mandatory disclosure stage, relatively large differences still lie in the disclosure willingness, disclosure degree, and disclosure time among various enterprises. So that it is in need of the help of government compulsory means 
to improve regulatory requirements, to spur the enterprise management level to fully understand the overall application trend of XBRL in enterprise management systems and reinforce the application of XBRL. Finally, for ordinary investors, subject to the limitations of cognitive and learning costs, the main channel for obtaining corporate financial information is still PDF financial reports, while the information advantages of XBRL financial reports have not been fully reflected, which requires relevant departments and enterprises increase the publicity and promotion of XBRL-related knowledge, make ordinary investors realize the advantages of XBRL financial reports, make XBRL technology further play its role in improving the capital market information efficiency.

The limitation of this study is that although the Chinese capital market requires all listed companies to disclose both PDF and XBRL format financial reports since 2008, in the actual application process, XBRL format financial reports have not achieved the expected using effects. That is, partial investors still make investment decisions with the help of traditional PDF financial reports, and the feedback of XBRL on firm-specific information has not been fully utilized. Therefore, in the follow-up research process, we will further carry out long-term tracking and observation on this issue, and carry out in-depth exploration of the economic consequences of XBRL application. 


\section{REFERENCES}

Alles, M., \& Piechocki, M. (2012). Will XBRL improve corporate governance?: A framework for enhancing governance decision making using interactive data. International Journal of Accounting Information Systems, 13(2), 91-108. doi:10.1016/j.accinf.2010.09.008

An, H., \& Zhang, T. (2013). Stock price synchronicity, crash risk, and institutional investors. Journal of Corporate Finance, 21, 1-15. doi:10.1016/j.jcorpfin.2013.01.001

Baldwin, A. A., Brown, C. E., \& Trinkle, B. S. (2006). XBRL: An Impacts Framework and Research Challenge. Journal of Emerging Technologies in Accounting, 3(1), 97-116. doi:10.2308/jeta.2006.3.1.97

Bartley, J., Chen, A. Y. S., \& Taylor, E. Z. (2011). A comparison of XBRL filings to corporate 10-Ks-Evidence from the voluntary filing program. Accounting Horizons, 25(2), 227-245. doi:10.2308/acch-10028

Birt, J. L., Muthusamy, K., \& Bir, P. (2017). XBRL and the qualitative characteristics of useful financial information. Accounting Research Journal, 30(01), 107-126. doi:10.1108/ARJ-11-2014-0105

Borges, M. R. (2010). Efficient market hypothesis in European stock markets. European Journal of Finance, 16(7), 711-726. doi:10.1080/1351847X.2010.495477

Boubaker, S., Mansali, H., \& Rjiba, H. (2014). Large controlling shareholders and stock price synchronicity. Journal of Banking \& Finance, 40, 80-96. doi:10.1016/j.jbankfin.2013.11.022

Chan, K., \& Chan, Y. C. (2014). Price informativeness and stock return synchronicity: Evidence from the pricing of seasoned equity offerings. Journal of Financial Economics, 114(1), 36-53. doi:10.1016/j.jfineco.2014.07.002

Chan, K., \& Hameed, A. (2006). Stock price synchronicity and analyst coverage in emerging markets. Journal of Financial Economics, 80(1), 115-147. doi:10.1016/j.jfineco.2005.03.010

Chan, K., Hameed, A., \& Kang, W. (2013). Stock price synchronicity and liquidity. Journal of Financial Markets, 16(3), 414-438. doi:10.1016/j.finmar.2012.09.007

Chen, G., Kim, J. B., Lim, J. H., \& Zhou, J. (2018). XBRL adoption and bank loan contracting: Early evidence. Journal of Information Systems, 32(2), 47-69. doi:10.2308/isys-51688

Chen, S. S., Li, W. Y., \& Wu, D. L. (2015). XBRL, corporate governance and cost of equity-Based on the full view of financial information value chain. Accountability in Research, 3, 64-71.

Choi, J. J., Sami, H., \& Zhou, H. (2010). The impacts of state ownership on information asymmetry: Evidence from an emerging market. China Journal of Accounting Research, 3, 13-50. doi:10.1016/S1755-3091(13)60018-0

Chung, R., Fung, S., Shilling, J. D., \& Simmons-Mosley, T. X. (2011). What determines stock price synchronicity in REITs? The Journal of Real Estate Finance and Economics, 43(1-2), 73-98. doi:10.1007/s11146-010-9254-3

Dong, Y., Li, O. Z., Lin, Y., \& Ni, C. (2016). Does Information-Processing Cost Affect Firm-Specific Information Acquisition? Evidence from XBRL Adoption. Journal of Financial and Quantitative Analysis, 51(2), $435-462$. doi:10.1017/S0022109016000235

Durnev, A., Morck, R., \& Yeung, B. (2004). Value-Enhancing Capital Budgeting and Firm-specific Stock Return Variation. The Journal of Finance, 59(1), 65-105. doi:10.1111/j.1540-6261.2004.00627.x

Durnev, A., Morck, R., Yeung, B., \& Zarowin, P. (2003). Does greater firm-specific return variation mean more or less informed stock pricing? Journal of Accounting Research, 41(5), 797-836. doi:10.1046/j.1475679X.2003.00124.X

Easley, D., \& O'hara, M. (2004). Information and the cost of capital. The Journal of Finance, 59(4), 1553-1583. doi:10.1111/j.1540-6261.2004.00672.x

Efendi, J., Park, J. D., \& Smith, L. M. (2014). Do XBRL filings enhance informational efficiency? Early evidence from post-earnings announcement drift. Journal of Business Research, 67(6), 1099-1105. doi:10.1016/j. jbusres.2013.05.051

Fama, E. F. (1970). Efficient Capital Markets: A Review of Theory and Empirical Work. The Journal of Finance, 25(2), 383-417. doi:10.2307/2325486 
Gabriela ğiĠan, A. (2015). The efficient market hypothesis: Review of specialized literature and empirical research. Procedia Economics and Finance, 32, 442-449.

Grossman, S. (1976). On the efficiency of competitive stock markets where trades have diverse information. The Journal of Finance, 31(2), 573-585. doi:10.1111/j.1540-6261.1976.tb01907.x

Gul, F. A., Kim, J. B., \& Qiu, A. A. (2010). Ownership concentration, foreign shareholding, audit quality, and stock price synchronicity: Evidence from China. Journal of Financial Economics, 95(3), 425-442. doi:10.1016/j. jfineco.2009.11.005

Hao, L., \& Zhang, , J., \& Fang, J. (2014). Does voluntary adoption of XBRL reduce cost of equity capital? International Journal of Accounting \& Information Management, 22(2), 86-102. doi:10.1108/ IJAIM-11-2012-0071

Harjoto, M. A., \& Jo, H. (2015). Legal vs. normative CSR: Differential impact on analyst dispersion, stock return volatility, cost of capital, and firm value. Journal of Business Ethics, 128(1), 1-20. doi:10.1007/s10551014-2082-2

Hasan, I., Song, L., \& Wachtel, P. (2014). Institutional development and stock price synchronicity: Evidence from China. Journal of Comparative Economics, 42(1), 92-108. doi:10.1016/j.jce.2013.07.006

Hodge, F. D., Kennedy, J. J., \& Maines, L. A. (2004). Does search-facilitating technology improve the transparency of financial reporting? The Accounting Review, 79(3), 687-703. doi:10.2308/accr.2004.79.3.687

Huang, J., \& Guo, Z. R. (2014). The effect of the media coverage on the pricing efficiency the capital market: An analysis based on the stock price synchronicity. Guanli Shijie, 5, 121-130.

Hutton, A. P., Marcus, A. J., \& Tehranian, H. (2009). Opaque financial reports, R2, and crash risk. Journal of Financial Economics, 94(1), 67-86. doi:10.1016/j.jfineco.2008.10.003

Janvrin, D. J., Pinsker, R. E., \& Mascha, M. F. (2013). XBRL-enabled, spreadsheet, or PDF? Factors influencing exclusive user choice of reporting technology. Journal of Information Systems, 27(2), 35-49. doi:10.2308/ isys-50569

Jin, L., \& Myers, S. C. (2006). R2 around the world: New theory and new tests. Journal of Financial Economics, 79(2), 257-292. doi:10.1016/j.jfineco.2004.11.003

Jin, Y., Yan, M., Xi, Y., \& Liu, C. (2016). Stock price synchronicity and stock price crash risk: Based on the mediating effect of herding behavior of QFII. China Finance Review International, 6(3), 230-244. doi:10.1108/ CFRI-05-2015-0047

Kelly, B., \& Ljungqvist, A. (2012). Testing asymmetric-information asset pricing models. Review of Financial Studies, 25(5), 1366-1413. doi:10.1093/rfs/hhr134

Kim, J., Kim, J. W., \& Lim, J. (2019). Does XBRL Adoption Constrain Earnings Management? Early Evidence from Mandated U.S. Filers. Contemporary Accounting Research, 36(4), 2610-2634. doi:10.1111/19113846.12493

Kim, J. B., \& Cheong, H. Y. (2015). Foreign versus domestic institutional investors in emerging markets: Who contributes more to firm-specific information flow? China Journal of Accounting Research, 8(1), 1-23.

Kim, J. B., \& Shi, H. (2012). IFRS reporting, firm-specific information flows, and institutional environments: International evidence. Review of Accounting Studies, 17(3), 474-517. doi:10.1007/s11142-012-9190-y

Kim, J. B., Yu, Z., \& Zhang, H. (2016). Can media exposure improve stock price efficiency in China and why? China Journal of Accounting Research, 9(2), 83-114. doi:10.1016/j.cjar.2015.08.001

Kim, J. W., Lim, J. H., \& No, W. G. (2012). The effect of first wave mandatory XBRL reporting across the financial information environment. Journal of Information Systems, 26(1), 127-153. doi:10.2308/isys-10260

Lai, S.-C., Lin, Y.-S., Lin, Y.-H., \& Huang, H.-W. (2015). XBRL adoption and cost of debt. International Journal of Accounting \& Information Management, 23(2), 199-216. doi:10.1108/IJAIM-04-2014-0031

Li, C. (2010). Savings, investment, and capital mobility within China. China Economic Review, 21(1), 14-23. doi:10.1016/j.chieco.2009.08.005 
Li, H., Li, Z., Lin, B., \& Xu, X. (2019). The effect of short sale constraints on analyst forecast quality: Evidence from a natural experiment in China. Economic Modelling, 81, 338-347. doi:10.1016/j.econmod.2019.06.001

Lin, K. J., Karim, K. E., \& Carter, C. (2015). Why does China's stock market have highly synchronous stock price movements? An information supply perspective. Advances in Accounting, 31(1), 68-79. doi:10.1016/j. adiac.2015.03.006

Liu, C., Wang, T., \& Yao, L. J. (2014). XBRL's impact on analyst forecast behavior: An empirical study. Journal of Accounting and Public Policy, 33(1), 69-82. doi:10.1016/j.jaccpubpol.2013.10.004

Liu, M. H. (2011). Analysts' Incentives to Produce Industry -level versus Firm -specific Information. Journal of Financial and Quantitative Analysis, 46(3), 757-784. doi:10.1017/S0022109011000056

Morck, R., Yeung, B., \& Yu, W. (2000). The information content of stock markets: Why do emerging markets have synchronous stock price movements? Journal of Financial Economics, 58(1-2), 215-260. doi:10.1016/ S0304-405X(00)00071-4

Piotroski, J. D., \& Roulstone, D. T. (2004). The Influence of Analysts, Institutional Investors, and Insiders on the Incorporation of Market, Industry, and Firm-Specific Information into Stock Prices. The Accounting Review, 79(4), 1119-1151. doi:10.2308/accr.2004.79.4.1119

Plumlee, R. D., \& Plumlee, M. A. (2008). Assurance on XBRL for financial reporting. Accounting Horizons, 22(3), 353-368. doi:10.2308/acch.2008.22.3.353

Premuroso, R. F., \& Bhattacharya, S. (2008). Do early and voluntary filers of financial information in XBRL format signal superior corporate governance and operating performance? International Journal of Accounting Information Systems, 9(1), 1-20. doi:10.1016/j.accinf.2008.01.002

Richards, J., Smith, B., \& Saeedi, A. (2006). An Introduction to XBRL. SSRN Electronic Journal. 10.2139/ ssrn. 1007570

Roll, R. (1988). R2. The Journal of Finance, 43(3), 541-566.

Roohani, S., Furusho, Y., \& Koizumi, M. (2009). XBRL: Improving transparency and monitoring functions of corporate governance. International Journal of Disclosure and Governance, 6(4), 355-369. doi:10.1057/ jdg.2009.17

Song, L. (2015). Accounting disclosure, stock price synchronicity and stock crash risk: An emerging-market perspective. International Journal of Accounting \& Information Management, 23(4), 349-363. doi:10.1108/ IJAIM-02-2015-0007

Vasarhelyi, M. A., Chan, D. Y., \& Krahel, J. P. (2012). Consequences of XBRL standardization on financial statement data. Journal of Information Systems, 26(1), 155-167. doi:10.2308/isys-10258

Xing, X., \& Anderson, R. (2011). Stock price synchronicity and public firm-specificinformation. Journal of Financial Markets, 14(2), 259-276. doi:10.1016/j.finmar.2010.10.001

Xu, N., Chan, K. C., Jiang, X., \& Yi, Z. (2013). Do star analysts know more firm-specific information? Evidence from China. Journal of Banking \& Finance, 37(1), 89-102. doi:10.1016/j.jbankfin.2012.08.014

Yoon, H., Zo, H., \& Ciganek, A. P. (2011). Does XBRL adoption reduce information asymmetry? Journal of Business Research, 64(2), 157-163. doi:10.1016/j.jbusres.2010.01.008

Zhang, Y., Guan, Y., \& Kim, J. B. (2019). XBRL adoption and expected crash risk. Journal of Accounting and Public Policy, 38(1), 31-52. doi:10.1016/j.jaccpubpol.2019.01.003 